Mеталлофиз. новейшие технол. / Metallofiz. Noveishie Tekhnol. @ 2018 ИМФ (Институт металлофизики 2018, т. 40, № 4, сс. 529-540 / DOI: $10.15407 /$ mfint.40.04.0529 им. Г. В. Курдюмова НАН Украины) Оттиски доступны непосредственно от издателя

Фотокопирование разрешено только

Напечатано в Украине.

в соответствии с лицензией

PACSnumbers: 61.72.Lk, 61.80.Ba, 61.82.Fk, 62.20.fq, 81.40.Lm, 81.40.Wx, 83.60.Np

\title{
Photoplastic Effect in Narrow-Gap Mercury Chalcogenide Crystals
}

\author{
B. P. Koman, O. O. Balitskii, and D. S. Leonov* \\ Ivan Franko National University of Lviv, \\ Faculty of Electronics and Computer Technologies, \\ 1 Universytetska Str., \\ UA-79000 Lviv, Ukraine \\ "Technical Centre, N.A.S. of Ukraine, \\ 13 Pokrovs'ka Str., \\ 04070 Kyiv, Ukraine
}

The paper elucidates the peculiarities of photoplasticization effect (PPE) occurring in narrow-gap crystals of mercury chalcogenides illuminated by white light during the process of uniaxial deformation. As found, the irradiation has an influence on the plastic deformation in narrow-gap $\mathrm{Cd}_{x} \mathrm{Hg}_{1-x} \mathrm{Te}$ crystals. Negative photoplasticization effect (NPPE) described here is concerned with reducing of plastic stress fluidity under white-light irradiation during plastic deformation of crystals at a constant rate. As found, in contrary to wide-bandgap crystals of the II-VI groups exhibiting positive PPE, NPPE observed in $\mathrm{Cd}_{x} \mathrm{Hg}_{1-x}$ Te occurs without internal photoeffect. A model explaining the nature of NPPE relies on a decreasing of positive charge in a native oxide layer at the surface of crystal. Charge decreasing reduces potential barrier for exiting on surface of dislocations generated by near-surface sources during dynamical loading. As a result, the level of fluidity stress in the deformed crystal is reduced.

Key words: photoplasticization effect, narrow-gap semiconductor, mercury chalcogenides, dislocations, deformation.

У роботі розглянуто особливості фотопластичного ефекту (ФПЕ), що виникає у вузькощілинних кристалах $\left(E_{g} \cong 0,2 \mathrm{eB}\right)$ халькогенідів ртуті, освітлених білим світлом, у процесі їх одновісної деформації. Встановлено,

Corresponding authors: Bohdan Petrovych Koman

E-mail: sonce_28@ukr.net

Citation: B. P. Koman, O. O. Balitskii, and D. S. Leonov, Photoplastic Effect in Narrow-Gap Mercury Chalcogenide Crystals, Metallofiz. Noveishie Tekhnol., 40, No. 4: 529-540 (2018), DOI: 10.15407/mfint.40.04.0529. 
що опромінення впливає на пластичну деформацію вузькощілинних кристалів твердих розчинів $\mathrm{Cd}_{x} \mathrm{Hg}_{1-x} \mathrm{Te}(x-$ молярний склад). Досліджений в роботі від'ємний фотопластичний ефект (ВФПЕ) пов'язаний зі зменшенням напруги пластичної плинности при опроміненні білим світлом в умовах одновісної пластичної деформації кристалу за постійної швидкости навантаження. Виявлено, що, на відміну від широкозонних кристалів сполук II-VI груп, які виявляють позитивний ФПЕ, в кристалах твердих розчинів $\mathrm{Cd}_{x} \mathrm{Hg}_{1-x}$ Te ВФПЕ спостерігається за відсутности внутрішнього фотоефекту. Модель, що пояснює природу ВФПЕ, грунтується на встановленому факті зменшення при освітленні кристалу позитивного заряду в оксидному шарі приповерхневої области кристалу. Зменшення заряду понижує потенціяльний бар'єр для виходу на поверхню дислокацій, що породжуються приповерхневими джерелами в процесі динамічного навантаження. Наслідком є зменшення напруги плинности деформації кристалу.

Ключові слова: фотопластичний ефект, вузькощілинні напівпровідники, халькогеніди ртуті, дислокації, деформація.

В работе рассмотрены особенности фотопластического эффекта (ФПЭ), наблюдаемого в узкощелевых $\left(E_{g} \cong 0,2\right.$ эВ) кристаллах халькогенидов ртути при облучении белым светом в процессе их одноосной деформации. Установлено, что облучение влияет на пластическую деформацию узкощелевых кристаллов твёрдых растворов $\mathrm{Cd}_{x} \mathrm{Hg}_{1-x} \mathrm{Te}(x-$ молярный состав). Исследованный в работе отрицательный фотопластический эффект (ОФПЭ) связан с уменьшением при облучении белым светом напряжения пластического течения в условиях пластической деформации кристалла с постоянной скоростью нагружения. Установлено, что, в отличие от широкозонных кристаллов соединений II-VI групп, проявляющих положительный ФПЭ, в кристаллах узкощелевых твёрдых растворов $\mathrm{Cd}_{x} \mathrm{Hg}_{1-x} \mathrm{Te}$ ОФПЭ наблюдается в отсутствие внутреннего фотоэффекта. Модель, объясняющая природу ОФПЭ, основывается на установленном факте уменьшения при освещении кристалла положительного заряда в оксидном слое приповерхностной области кристалла. Этот процесс понижает потенциальный барьер для выхода на поверхность дислокаций, порождаемых приповерхностными источниками в процессе динамического нагружения. Следствием является уменьшение напряжения пластического течения кристалла.

Ключевые слова: фотопластический эффект, узкощелевые полупроводники, халькогениды ртути, дислокации, деформация.

(Received March 21, 2018)

\section{INTRODUCTION}

As recently described in Refs. [1-3], variation of electron-subsystem states in semiconducting materials essentially influences dislocation movement conditions. In particular, irradiation induces changes of 
point defect and dislocations charges in a crystal and affects the interaction between mobile dislocations and effective stoppers. A striking example of the external factors influencing a plastic deformation stress is the photoplasticization effect (PPE). It changes fluidity stress in the crystal excited by intrinsic absorption under dynamical loading within the plastic deformation region. PPE is much less studied as compared to magnetoplastic effect where atomic mechanisms have already been drawn [4-7] mainly due to practical implementation of the effect.

Nadeau discovered PPE in alkali halide crystals [8]. In more details, its nature was studied in [9], followed by the quantitative mathematical model with estimated values of plasticity shifts [10]. PPE in widebandgap II-VI-groups compounds was described in [11]. It was found that irradiation of CdS under plastic deformation with visible light leads to hardening and plastic deformation shifts towards increased values of shear stress. Generalization of experimental results on PPE in above-mentioned compounds was done by Osip'yan and Petrenko [12]. An important fact for understanding the nature of this effect was elucidation of the role of nonequilibrium carriers generated by an internal photoeffect in the processes of changing the charge state of point defects and mobile dislocations. It was found that light exciting PPE significantly increases the linear charge density of dislocations [12]. Namely, there is a correlation between the changes of deforming tension and dislocation charge density. Therefore, the dislocation mobility decrease can be natured from its charge rise. It was established that the charge of mobile dislocations is generated by electrons collected by trap levels [3]. As the number of electrons at these levels grows, the dislocation charge increases and dislocation mobility reduced. Irradiation of a crystal with bandgap matched light stimulates number of traps filled with electrons, leading to an increase in the dislocations charge. Alternative view of the PPE nature in wide-bandgap semiconductor crystals is based on the changes of movement kinetics under irradiation and multiplication of the double bends number during the plastic deformation of a crystal [1]. Since PPE is a typical phenomenon for wide-bandgap crystal of $A^{2} B^{6}$ family (for example, CdTe exhibits positive and negative PPE) [14, 15], it is interesting to examine manifestation of this effect in narrow-band crystals belonging to ternary $\mathrm{Cd}_{x} \mathrm{Hg}_{1-x} \mathrm{Te}$ semiconductors $(x=0.16-$ $0.22)$ with $E_{g} \cong 0.1 \mathrm{eV}$. We are aiming the present work to study the features of PPE in mixed $\mathrm{Cd}_{x} \mathrm{Hg}_{1-x} \mathrm{Te}$ crystals and to establish the physical nature of this phenomenon.

\section{MATERIALS AND METHODS}

Single crystal samples of $\mathrm{Cd}_{x} \mathrm{Hg}_{1-x} \mathrm{Te}$ solid solution $(x=0.16-0.22)$ were grown by Bridgman and solid-state recrystallization methods. 
Own oxide was formed on the surface of a crystal sealed in an oxygen filled ampoule during thermal annealing at $200^{\circ} \mathrm{C}$ for 24 hours in order to master under-gate insulator. Deformation of the samples $(2 \times 2 \times 6$ $\mathrm{mm}^{3}$ ) was performed on a Regel-Dubov relaxometer along the longer crystal edge at a constant rate. The rate of deformation was chosen in the range $2 \cdot 10^{-6}-9 \cdot 10^{-5} \mathrm{~s}^{-1}$. Irradiation of the sample in the process of deformation was carried out by using of two different methods: i) white light from an incandescent lamp $(P=20 \mathrm{~W}$, flux $80 \mathrm{~lm})$ or ii) continuous $\mathrm{CO}_{2}$ laser operating at $\lambda=10.6 \mu \mathrm{m}$. For the generation of light pulses, mechanical shutter camera was used, producing light pulses with 1 to 100 s periodicity. Experimental measurements of voltagecapacitance characteristics (VCCs) were conducted at the frequency of $10 \mathrm{kHz}$ test signal with linear voltage sweep rate of $10^{-2} \mathrm{~Hz}$.

\section{RESULTS AND DISCUSSION}

Figure 1 illustrates a typical stress-strain diagram with the photosoftening (PS) effect for $\mathrm{Cd}_{0.2} \mathrm{Hg}_{0.8}$ Te crystal. The white-light irradiated crystal under uniaxial deformation possesses initially a step-like change of fluidity tension. Then, the radiation induced rapid decrease is observed (i.e. NPPE) and the crystal continues to deform with the previous coefficient of deformation hardening. As the light is turned off, deformation restores at the initial value. This phenomenon occurs repeatedly until the sample is destroyed. The described effect was observed with the absence of photoconductivity in the temperature range of $290-430 \mathrm{~K}$.

The systematic study of NPPE stress curves indicates that steady stress fluidity is not achieved immediately after light is switched

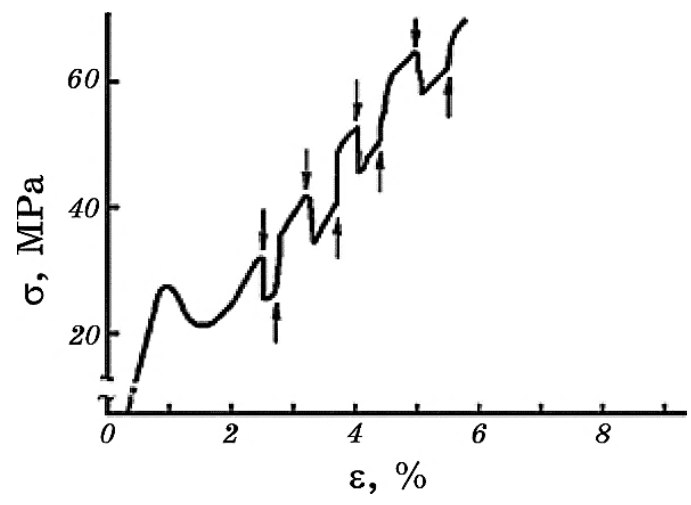

Fig. 1. Negative photoplasticization effect in $\mathrm{Cd}_{0,2} \mathrm{Hg}_{0,8}$ Te crystal ( $\uparrow$-light on, $\downarrow$-light off); $V=5.85 \cdot 10^{-3} \mathrm{~mm} / \mathrm{min}, T=300 \mathrm{~K}$. The white light from an incandescent lamp was used for irradiation. 
on/off, but there is a delay namely a relaxation time. Thus, a memory effect is observed while previous level of deforming stress is reached. Such behaviour can be natured from two types of processes. In one hand, characteristic times for electronic subsystem to reach the equilibrium are sufficiently long and substantially dependent on temperature. In the other hand, light induced tension growth can be connected with the restructuring of the dislocation structure. The latter depends on the area of the total plastic deformation accumulated in the sample. The relaxation time growth at the higher degree of deformation can be explained by increasing of dislocation density. In addition, changes in a point defects system are accompanied by variations in conditions of their movement and reproduction. In this case, mercury vacancies in $\mathrm{Cd}_{0.2} \mathrm{Hg}_{0.8} \mathrm{Te}$ serve as efficient centres for interaction with mobile dislocations [16].

Typical experimental dependencies of PS on deformation level for $\mathrm{Cd}_{0.2} \mathrm{Hg}_{0.8} \mathrm{Te}$ crystals with different degree of the stoichiometry deviation are shown in Fig. 2.

All the samples possess a common feature: PS value decreases with the plastic deformation accumulated. However, crystals with different deviations from stoichiometry show different decrease tendencies. In particular, sample with electronic conductivity $\left(n=10^{15} \mathrm{~cm}^{-3}\right)$ manifests a linear behaviour. For the sample with hole conductivity ( $p=$ $=8 \cdot 10^{16} \mathrm{~cm}^{-3}$ ), such a dependence consists of two sections. Primarily, the value of PS drops sharply down to $50 \%$, and then changes slightly reaching a saturation at large values strain. The smallest changes for PS are observed in the sample with intrinsic conductivity $(p=n)$ : the value of the effect reaches as little as $20 \%$. As discussed above, $\mathrm{Cd}_{x} \mathrm{Hg}_{1-x} \mathrm{Te}$ crystals are characterized by a memory effect to the previous deforming stress. In order to draw a physical model of the effect, one must gather information about the lifetimes of the centres responsible for the observed PPE. For this purpose, we have studied the effect

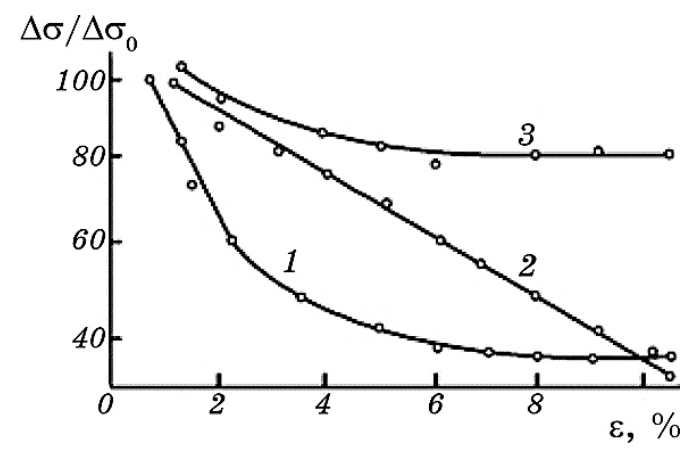

Fig. 2. Relative PS in $\mathrm{Cd}_{0.2} \mathrm{Hg}_{0.8}$ Te crystals as a function of strain degree: $1-$ $p=8 \cdot 10^{16} \mathrm{~cm}^{-3}, 2-n=10^{15} \mathrm{~cm}^{-3}, 3-p=n$. 
of pulsed irradiation on the kinetics of the PS (Fig. 3).

It is evident that the PS characteristic can by divided into three consecutive stages. The first corresponds to the rapid growth (up to $5 \mathrm{~s}$ ) while at the second (up to $33 \mathrm{~s}$ ) the growth rate becomes slightly slower. The final stage corresponds to a saturation of the PS effect. Typically, during performed experiments a steady state is reached after approximately $80 \mathrm{~s}$ of irradiation. That can be explained as follows. Initially, a certain amount of PS softening centres is photogenerated in a crystal, and then their concentration exponentially decreases after light is turned off. Each centre corresponds to the exact type of deforming stress. However, total stress is a combined result of interaction of mobile dislocations with conservative and non-conservative centres in irradiated crystal and not following the concentration of photosensitive centres. The rate of such changes depends on the deformation and plastic properties of the sample. In this regard, stress decreases were postponed after switching the light off. Due to suffi-

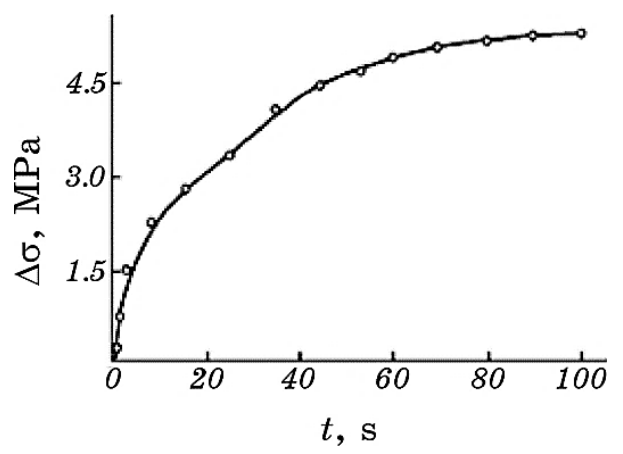

Fig. 3. The PS dependence on irradiation pulse duration.

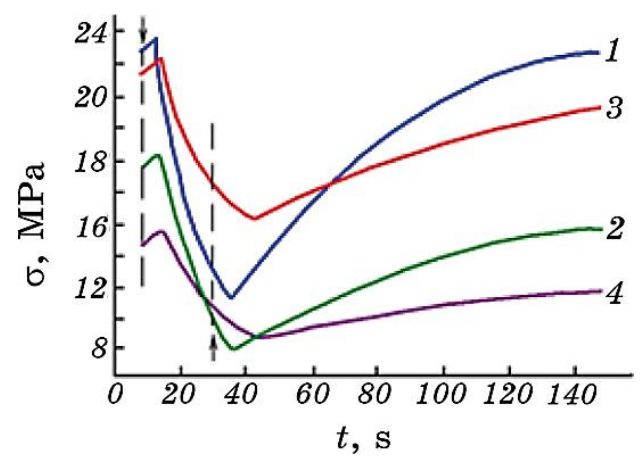

Fig. 4. PS effects after different rates of loading for $\mathrm{Cd}_{0.2} \mathrm{Hg}_{0.8} \mathrm{Te}$ crystals: $1-$ $2.34 \cdot 10^{-2} \mathrm{~mm} / \mathrm{min}, \quad 2-5.85 \cdot 10^{-3} \mathrm{~mm} / \mathrm{min}, 3-2.93 \cdot 10^{-3} \mathrm{~mm} / \mathrm{min}, 4-$ $1.46 \cdot 10^{-3} \mathrm{~mm} / \mathrm{min}$. 
ciently longer centre lifetimes, the concentration of centres during certain period of time is not matching with achieved deforming stress. Decrease of mechanical stress is terminated when the stress values and the centres' concentration are matched. Further increase of the deforming stress is due to the subsequent decrease of the centres' concentration. Growth of the deformation rate is accompanied by more rapid achievement of consistency between the deforming stress and the centres' concentration. Therefore, the time of the aftereffect decreases and the value of PPE increases.

According to the technique suggested in [17], one should combine curves related to different strain rates (Fig. 4). Combined dependences (Fig. 5) will be further used to elucidate PPE parameters.

That dependence is linearized in semi-logarithmic scale in Fig. 5, $b$. The centres lifetime deducted is about 6 seconds. Investigation of temperature dependencies of centres lifetime responsible for PPE in the existence region (300-400 K) allowed estimating the activation energy of thermal destruction, which is equal to $0.34 \mathrm{eV}$. It was found that the highest value of lifetime for PPE centres has been observed for the samples highly manifested PS effect. Therefore, we assume that the magnitude of the PS effect is proportional to the lifetime of the centres responsible for PPE. In other words, the PPE in narrow-gap $\mathrm{Cd}_{x} \mathrm{Hg}_{1-x} \mathrm{Te}$ crystals is not natured by interaction of charged dislocations with photosensitive centres as for the case of binary widebandgap crystals of II-VI-groups' family.

It should be noted that the manifestation of PPE under visible light excitation is not expected in the narrow-band materials $(\cong 0.1 \mathrm{eV})$. The attempts to draw the appropriate model based on the generation of non-equilibrium carriers' theory as was done for wide gap have not yet been successful. Let us now focus on some aspects describing unusual nature of this effect in ternary $\mathrm{Cd}_{x} \mathrm{Hg}_{1-x} \mathrm{Te}$ crystals and compare them

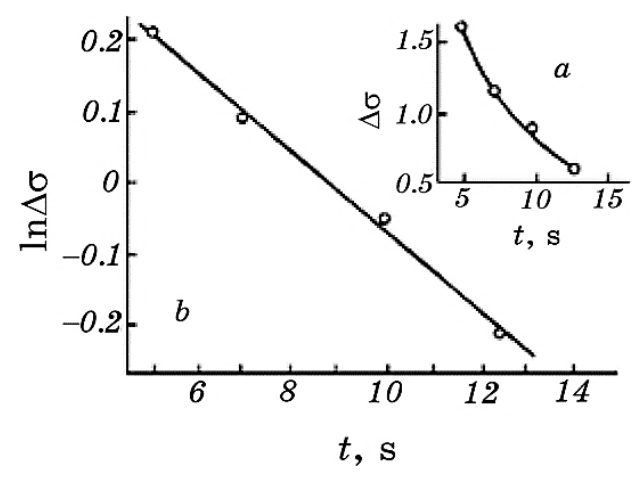

Fig. 5. The plot determines the lifetime of the centres responsible for PPE in $\mathrm{Cd}_{0.2} \mathrm{Hg}_{0.8}$ Te crystals. 
with those of wide-bandgap II-VI-groups crystals. In particular, i) NPPE is observed in narrow-bandgap crystal $\mathrm{Cd}_{x} \mathrm{Hg}_{1-x} \mathrm{Te}$ excited by white light $(\lambda=0.35-2.5 \mu \mathrm{m})$ being beyond the absorption range. Thus, the internal photoeffect responsible for the positive PPE in $A^{2} B^{6}$ compounds is not manifested. Some samples manifest the effect under laser irradiation with the wavelength of $\lambda=10.6 \mu \mathrm{m}\left(\mathrm{CO}_{2}\right.$ laser $)$ at room temperature. ii) PPE is observed in crystals with stable own oxide layer. iii) Relaxation times are rather large establishing the permanent stress deformation after switching the light on and off in NPPE experiment. At sufficiently low values for Peierls barriers for mobile dislocations $(0.14-0.41 \mathrm{eV})$ in $\mathrm{Cd}_{x} \mathrm{Hg}_{1-x} \mathrm{Te}$ crystals [16], one should expect the influence of oxide layer on the dislocation-related processes at the near-surface layer during the entire time of dynamical loading of crystals. Primarily, we observe the inception of dislocations with subsequent transformation of dislocation structure as described by kinetics of deformation processes [18].

Key factors in the development of physical processes in near-surface layer should are properties of the oxide layer (adhesion, band gap, optical characteristics etc.). Therefore, under the influence of external factors such as incident light, observed effects are different: positive PPE in CdTe or NPPE in $\mathrm{Cd}_{x} \mathrm{Hg}_{1-x} \mathrm{Te}$. In contrary to binary compounds, ternary $\mathrm{Cd}_{x} \mathrm{Hg}_{1-x} \mathrm{Te}$ own oxide has significantly larger number of components drastically affecting physics and chemistry of surface. An example of such influence is a long-time relaxation of photoconductivity observed in $\mathrm{Cd}_{x} \mathrm{Hg}_{1-x} \mathrm{Te}$ crystals, which is characterized by time up to several minutes [19]. In particular, studied objects are characterized by uneven distribution of $\mathrm{Hg}$, $\mathrm{Te}, \mathrm{Cd}$ and $\mathrm{O}$ and the own oxide growth orientation directed towards the crystal bulk. The chemical composition is a mixture of $\mathrm{CdO}, \mathrm{CdTeO}_{3}, \mathrm{TeO}_{2}$, and $\mathrm{HgTeO}_{3}$ [20]. Oxide layer has a relatively high density of positive embedded charge $\left(6 \cdot 10^{11}\right.$ $1 \cdot 10^{12} \mathrm{~cm}^{-2}$ ), fast surface states with the density of $2.6 \cdot 10^{11} \mathrm{~cm}^{-2}$ and slow states with the density of $1 \cdot 10^{11} \mathrm{~cm}^{-2}$. The near-surface layer of the crystal is a classic insulator-semiconductor junction with positive embedded charge and the expected electric field of $10^{2}-10^{4} \mathrm{~V} / \mathrm{sm}$. To analyse the charge distribution in the light excited intrinsic oxidesemiconductor system in the PPE experiments, we studied the VCC of MOS-structures based on $n-\mathrm{Cd}_{0.25} \mathrm{Hg}_{0.75} \mathrm{Te}$ (Fig. 6).

VCC plots of MOS-structures are presented in Fig. 7. It was established that initial VCC is shifted by value of VCB $=-2.5 \mathrm{~V}$ in respect to ideal characteristic. Such a shift is natured by an existence of effective positive charge in the undergate insulator. Stimulated by irradiation, a significant offset of voltage planar zones towards positive values appeared. Moreover, a number of excited electrons changes the surface condition undergate from enriched to inverse. Reverse offset of voltage planar zones occurs when the structure is placed in a dark area. 
Time needed for the full recovery to initial VCC at $T=300 \mathrm{~K}$ is $30-$ $150 \mathrm{~s}$.

The most important result of studies establishing the nature of PPE is a radiation induced reduction of effective positive charge in the insulator relaxing after switching off the light with a time constant of $\cong 30-60 \mathrm{~s}$. Increasing of the exposure time is accompanied by higher relaxation times of nonequilibrium charge. Let us briefly analyse the optical properties of typical oxides on the surface of the $\mathrm{Cd}_{x} \mathrm{Hg}_{1-x} \mathrm{Te}$ crystals. CdO, according to [21], possesses $70-80 \%$ of transparency at 500-800 nm wavelengths. Paratellurite $\mathrm{TeO}_{2}$ has much broader range of transparency: $80 \%$ within $0.36-5.0 \mu \mathrm{m}$ window [22]. Hence, multicomponent native oxide layer on the surface of $n-\mathrm{Cd}_{x} \mathrm{Hg}_{1-x} \mathrm{Te}$ structure is transparent in almost entire spectrum range of incandescent lamp down to the insulator-semiconductor interface. Assuming the average band gap of the oxide layer to be about $3.4 \mathrm{eV}$ and band gap of the contacting semiconductor $\cong 0.2 \mathrm{eV}$, the photoinduced charge in the oxide can be explained by external photoemission of electrons from the va-

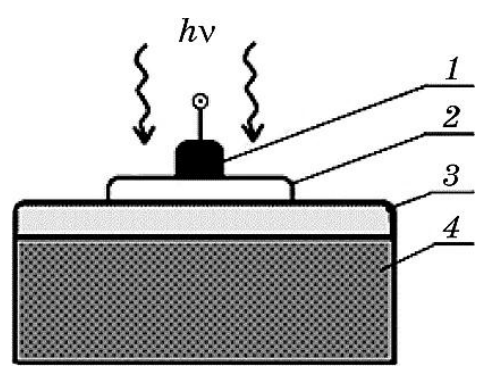

Fig. 6. Sketch of MOS structure based on $n$-CdHgTe with semi-transparent gate: 1 -gate electrode, 2-semi-transparent gate, 3-undergate insulator, $4-\mathrm{Cd}_{0.25} \mathrm{Hg}_{0.75} \mathrm{Te}$.

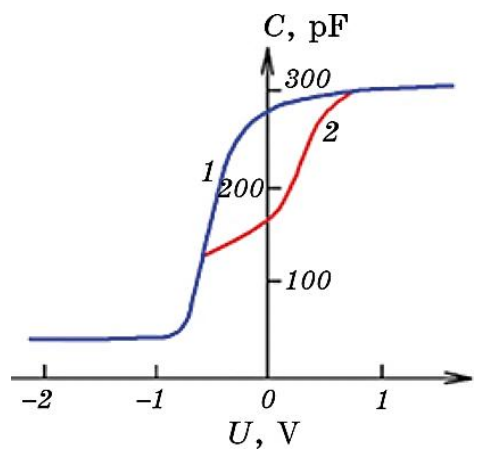

Fig. 7. VCCs for initial (1) and irradiated for $80 \mathrm{~s}$ by visible light (2) $\mathrm{CdHgTe}$ MOS structures. 
lence band of the semiconductor oxide into the conduction band of oxide followed by their capturing at traps in the oxide (Fig. 8), which are localized near the oxide-semiconductor interface.

Thus, the neutralization of fixed charge in oxide is realized. Probable mechanism of the electrons injection is the tunnelling of carriers through the interface. The energy of visible light $(\cong 0.6 \mu \mathrm{m})$ is close to the value of the oxide-semiconductor energy barrier. When the structure is placed in dark, conditions for thermal generation of electrons captured at traps and their further recombination in the semiconductor exist. Generally, excitation of studied crystals with visible light is accompanied by a decrease in the effective positive charge at the insulator-semiconductor interface.

Such a behaviour of the charge results in reduced mechanical stress on the interface, and reduced barrier for generated dislocations exit on the surface of the crystal in the process of deformation. These factors stimulate the lowering of the fluidity stress level in the deformed crystal with simultaneous irradiation (NPPE). Schematic representation of such processes is shown in Fig. 9.

As known, interface interaction is natured from physical, chemical, thermodynamical and mechanical incompatibilities between interaction materials [23]. The parameters characterizing above-mentioned interaction are interface energy and tension $\gamma_{m}$ and $\sigma_{m}$, respectively. The model elaborated [24] combines equations of nonequilibrium thermodynamics and surface physics describing mechanical stresses and charges at the interface. After applying such calculations, as was done in [25], the values for $\mathrm{Cd}_{x} \mathrm{Hg}_{1-x} \mathrm{Te}-$ own oxide system are as follow: $\gamma_{m}=0.893 \mathrm{~J} / \mathrm{m}^{2}, \sigma_{m}=0.739 \mathrm{~N} / \mathrm{m}$. Those parameters are as much as five time lower than that for $\mathrm{Si}-\mathrm{SiO}_{2}$ [26]. Therefore, the interface interaction in $\mathrm{Cd}_{x} \mathrm{Hg}_{1-x} \mathrm{Te}$-own oxide system is rather weak and can effective-

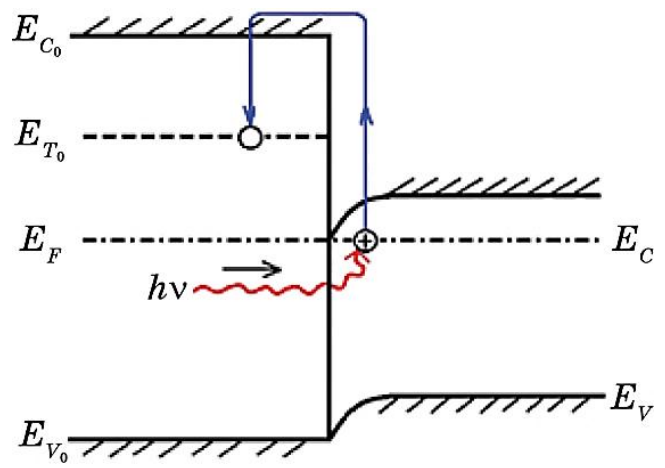

Fig. 8. Sketch of energy diagram of the 'own oxide $-n-\mathrm{Cd}_{x} \mathrm{Hg}_{1-x} \mathrm{Te}(x \cong 0.24)$ crystal' interface, illustrating the reduction of positive embedded charge in the insulator excited by white light. 


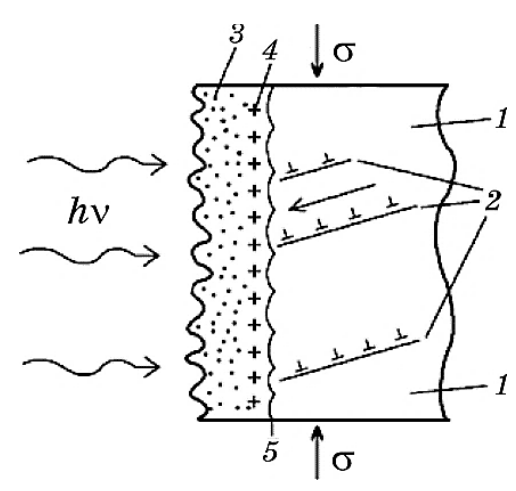

Fig. 9. Model representing the processes in uniaxially deformed $\mathrm{Cd}_{x} \mathrm{Hg}_{1-x} \mathrm{Te}$ crystal (the implementation of negative PPE): 1-deformed single crystal, 2 -dislocation slipping planes and directions of their movement, 3-oxide layer on the surface of a crystal, 4-positive charge embedded in the insulator on the intrinsic oxide-semiconductor interface, 5-intrinsic oxide-single crystal boundary.

ly be tuned by irradiation. As we mentioned, the mechanism of such tuning lies in the decrease of embedded insulator charge. Note, the presence of own oxide film on the CdHgTe surface eliminates the possibilities of periodic structures formation under combined effect of light pressure and mechanical stresses as was illustrated in [27]. CdHgTe own oxide is impenetrable by white light making processes of self-organization under macroscopic plastic deformation impossible [28].

\section{CONCLUSIONS}

1. Negative PPE is discovered in $\mathrm{Cd}_{x} \mathrm{Hg}_{1_{-x}} \mathrm{Te}$ crystals manifested in reduced fluidity stress in these crystals excited with white light during dynamical loading at a constant rate at the stage of plastic fluidity.

2 . VCCs of MOS structures based on $n-\mathrm{Cd}_{x} \mathrm{Hg}_{1-x}$ Te indicate that whitelight excitation effectively decreases the positive charge in the insulator by means of injecting electrons from the valence band to the trap in semiconductor oxide, spatially localized near the oxide-semiconductor interface. Possible mechanism of the injection is electrons tunnelling through the interface.

3. NPPE in narrow-bandgap $\mathrm{Cd}_{x} \mathrm{Hg}_{1-x}$ Te crystals is natured from the reduction in mechanical stress under the influence of light due to the decrease of the embedded positive charge at own oxide-semiconductor boundary. It is accompanied by the lowering of deformation barrier for the exit of generated dislocations on the surface, resulting in reduced level of fluidity stress in the deformed crystal under irradia- 
tion.

\section{REFERENCES}

1. T. Suzuki, Dislocation Dynamics and Plasticity. Overview (New York: Springer-Verlag: LLC: 2011).

2. F. R. N. Nabarro, Theory of Crystal Dislocations (Oxford University Press: 1967).

3. F. Herbert Matare, Defects Electronics in Semiconductors (New York-LondonSydney-Toronto: John Wiley and Sons: 1971).

4. M. I. Molotskii, R. E. Kris, and V. Fleurov, Phys. Rev. B, 51: 12531 (1995).

5. $\quad$ R. B. Morgunov, Physics Uspekhi, 174: 131 (2004).

6. M. Badylevich, Yu. L. Lumin, V. V. Kveder, V. I. Orlov, and Yu. Osipyan, Solid State Phenom., 95-96: 433 (2004).

7. E. V. Darinskaya, E. A. Petrznik, S. A. Erofeeva, and V. P. Kisel, Solid State Phenom., 69-70: 503 (1999).

8. J. S. Nadeau, J.Appl. Phys., 35, Iss. 3: 669 (1964).

9. J. M. Cabrera, J.Appl. Phys., 55, Iss. 5: 1013 (1974).

10. S. Gestrin and K. Koshelaevskaya, Proceedings of Voronezh State University. Series: Physics, Mathematics, 4: 511 (2017).

11. Yu. A. Osip'yan and I. B. Savchenko, JETP Letters, 77: 130 (1968).

12. Yu. A. Osip'yan and V. F. Petrenko, Dokl.Akad. Nauk SSSR, 226: 803 (1976).

13. L. G. Kirichenko and V. F. Petrenko, ZhETF, 74: 742 (1978).

14. C. N. Ahlguist, M. J. Carrol, and P. Stroempl, J. Phys. Chem. Sol., 33: 337 (1972).

15. E. Y. Gutmanas, N. Travitzky, and P. Haasen, phys. status solidi (a), 51: 435 (1979).

16. B. P. Koman, Ukr.J.Phys., 32: 908 (1987).

17. G. A. Ermakov, E. V. Korovkin, Yu. A. Osip'yan, and M. Sh. Shihsaidov, Solid State Phys., 17: 2364 (1975).

18. B. P. Koman, Physics and Chemistry of Solid State, 12, No. 4: 1018 (2011) (in Ukrainian).

19. M. S. Tyagl, Introduction to Semiconductor Materials and Devices (New YorkToronto-Singapure: John Wiley and Sons: 2001).

20. C. R. Helms, J.Vacuum Sci. Techn. A, 8: 1178 (1990).

21. D. J. Seo, Journal of the Korean Phys. Society, 45: 1575 (2004).

22. J. S. Wang, E. M. Vogel, and E. Snitzer, Optical Mater., 3: 187 (1994).

23. V. Misol, Surface Energy of Phase Separation in Metals (Moscow: Metallurgiya: 1978).

24. V. M. Yuzevych and B. P. Koman, Phys. Solid State, 56: 895 (2014).

25. V. M. Yuzevych, B. P. Koman, and R. M. Dzhala, J. Nano- Electron. Phys., 8, No. 4: 04005 (2016).

26. B. P. Koman, Sensor Electronics and Microsystem Technologies, 13, No. 2: 84 (2016).

27. N. V. Klassen, A. A. Vasin, and K. A. Polyanin, Materialovedenie, No. 10: 7 (2017).

28. N. P. Kobeleva, M. A. Lebyodkin, and T. A. Lebedkina, Metallurgical and Materials Transactions A, 48, No. 3: 965 (2017). 